\title{
Fyra sekler av judiskt liv i Sverige
}

\author{
BOKRECENSION
}

DOI: https://doi.org/10.30752/nj.111988

Carl Henrik Carlsson: Judarnas historia i Sverige (Stockholm: Natur \& Kultur, 2021). 400 sidor.

Jämfört med många andra länder utgör judarna i Sverige varken någon gammal eller stor grupp. Men i en svensk kontext är den av betydelse: judarna har numera status som en nationell minoritet och trots deras ringa antal har de påverkat samhället i hög grad. Kända svenska fenomen som Göteborgsvitsen, Barnens dag, Gustav Adolfsbakelsen, skolämnet slöjd och musiken till Idas sommarvisa har alla judar som upphovspersoner.

Det är därför välkommet att det nu utkommit en utförlig beskrivning av judarnas historia i Sverige, skriven av Carl Henrik Carlsson, historiker verksam vid Uppsala universitet. Senast det begav sig var 1924 då Hugo Valentin utgav en bok med samma titel som denna. Valentins bok utkom också i en populariserad, uppdaterad och förkortad version I964, men det har hänt mycket sedan dess.

Carlssons bok fyller inte bara ett tomrum. Den är också väldisponerad och välskriven. Många fakta presenteras men träden skymmer inte skogen; man ser de stora linjerna. Det är helt enkelt en njutning att läsa denna balanserade översikt av den svensk-judiska historien.

Aaron Isaac från Mecklenburg brukar framställas som Sveriges första jude. Judar

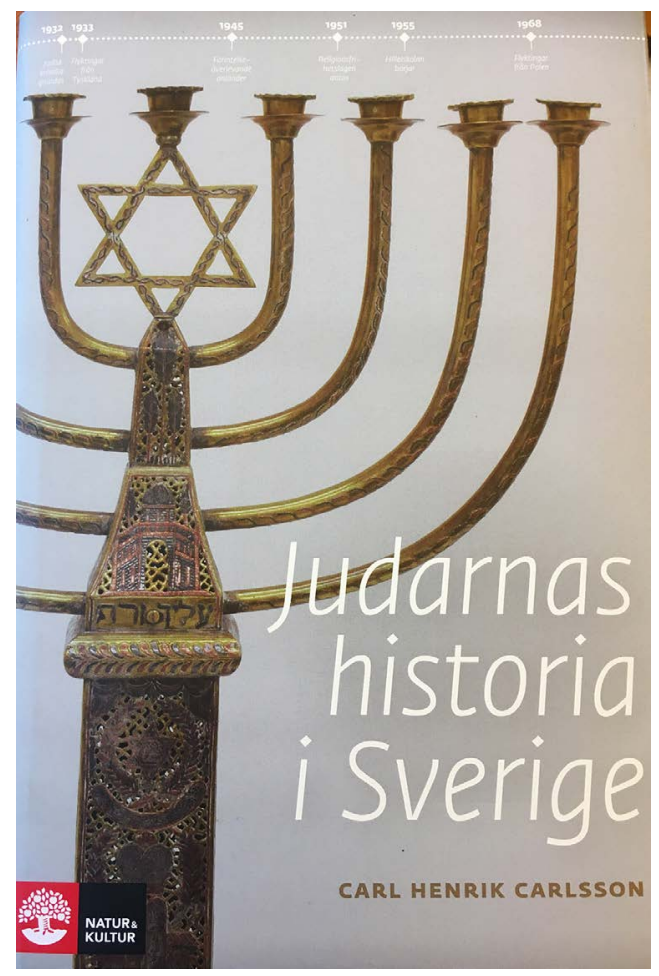

hade besökt landet tidigare, men det var ändå ett trendbrott då Isaac och några andra judar med sina familjer tilläts bosätta sig i Stockholm på I 770-talet och behålla sin religion. En intressant detalj är att det ända fram till den slutliga emancipationen r 870 i regel var så att kungarna ville underlätta för judisk invandring, medan motståndet $\mathrm{i}$ andra delar av samhället ofta var starkt.

Trots en långvarig och ihärdig vardagsantisemitism liberaliserades lagen och alltfler 
judar sökte sig till Sverige. Från och med slutet av I 8oo-talet kom alltfler östjudar, vilket skapade en del spänningar med de etablerade judiska familjerna som härstammade från Tyskland och vid det här laget var välintegrerade. Senare har den judiska folkgruppen i Sverige ökat i antal framför allt genom invandring av överlevande från koncentrationslägren efter andra världskrigets slut och av polska judar i slutet av i96o-talet.

I sin framställning följer Carlsson oftast ett klart mönster. För varje tidsperiod anges hur lagstiftningen förändrades, varifrån den judiska invandringen kom, hur församlingslivet utvecklades samt hur olika judar gjorde betydande insatser inom näringsliv, kultur, vetenskap och politik. Roliga anekdoter återges, som denna: "När Karl Warburg skulle bli ordförande i Göteborgsförsamlingen I 896 tyckte hans hustru Betty att det var'idiotiskt'; han hade ju inte satt sin fot i synagogan på fem år!" (s. I79)

Det judiska livet i Sverige har varit koncentrerat till storstäderna, men det har funnits församlingar och synagogor under olika tider i en lång rad städer som Karlskrona, Sundsvall, Halmstad, Kristianstad, Karlstad, Borås m.fl. Carlsson gör en viktig distinktion mellan de facto-församlingar, församlingar som finns och verkar, och de jure-församlingar, församlingar som officiellt registrerats. Under I 80o-talet krävdes statligt godkännande för att bli en officiell församling, något som inte alltid gavs. Under I 9oo-talet tynade flera av de små församlingarna bort.

Något som Carlsson med rätta understryker är att judarna i Sverige aldrig utgjort någon homogen grupp. Tvärtom har den varit splittrad på olika sätt: mellan östjudar och västjudar, ortodoxa och reformsinnade, religiösa och sekulära, sionister och icke-sionister. Långtifrån alla, idag en majoritet, av dem som enligt den halakhiska definitionen är judar och som själva betraktar sig som judar hör till en judisk församling sedan det i och med religionsfrihetslagen I 95 I blev möjligt för judar att gå ur en judisk församling utan att konvertera. Församlingarna hade befarat massflykt, men någon sådan ägde inte rum. Tvärtom ökade medlemsantalet eftersom den nya församlingsförordningen gjorde det möjligt att vara medlem utan att vara svensk medborgare. Församlingarna betecknades länge som "mosaiska"; först omkring r 980 bytte de namn så att man idag till exempel talar om "Stockholms judiska församling".

Ett viktigt tema i boken är det omgivande samhällets syn på judarna och därmed också antisemitismen. Det paradoxala är ju att jämfört med andra länder är andelen av Sveriges befolkning som hyser antisemitiska åsikter låg, samtidigt som varenda judisk institution i landet måste ha minutiösa säkerhetsrutiner.

Boken är inte bara informativ och välskriven. Den är också välutformad. Tryck- och sakfelen är få (Pragvåren är dock feldaterad, s. 3 I 8). Ett plus för de ofta fyndiga kapitelrubrikerna, inte sällan citat. Som detta för perioden I99I-202 I: "En jude läser gärna Judisk Krönika, men inte på bussen" (s. 327). Däremot hade boken gärna fått innehålla översiktstabeller över till exempel antalet judar i de olika församlingarna vid olika tider, över rabbiner, ordföranden och kantorer i församlingarna, och liknande.

Författaren spekulerar inte om framtiden, men har några tankar:
Vad som definitivt kan sägas är att större judiska flyktingvågor inte längre är demo- grafiskt nödvändiga, den nuvarande judiska minoriteten är tillräckligt stor för att "stå på egna ben” även utan invandring. Den judiska kulturen spirar som aldrig förr och erbjuder ett omfattande "smörgåsbord", till stor del också integrerat i den svensk- nationella kulturen. Samtidigt pågår en inomjudisk debatt och konflikt mellan 
exempelvis religiös observans och "kulturjudendom”, mellan "jiddischkeit” och övrig judisk kultur, mellan utåtriktad verksamhet och inre sammanhållning och kring relationen till Israel. En fråga som kan ställas är också huruvida det ökade intresset för Förintelsen på sikt kommer att kväva eller stimulera intresset för annan judisk historia och kultur. Det tål att upprepas: den judiska historien och närvaron i Sverige är mångfacetterad och heterogen. (s. 348)

Denna mångfacetterade och heterogena judiska historia och närvaro har Carl Henrik Carlsson förtjänstfullt beskrivit i denna bok.

SVANTE LUNDGREN

Docent i judaistik, Åbo Akademi och forskare vid Lunds universitet 